\title{
KLASIFIKASI REGRESI LOGISTIK MULTINOMIAL DAN FUZZY K-NEAREST NEIGHBOR (FK-NN) DALAM PEMILIHAN METODE KONTRASEPSI DI KECAMATAN BULAKAMBA, KABUPATEN BREBES, JAWA TENGAH
}

\author{
Erysta Risky Rismia ${ }^{*}$, Tatik Widiharih ${ }^{2}$, Rukun Santoso ${ }^{3}$ \\ 1,2,3 Departemen Statistika, Fakultas Sains dan Matematika, Universitas Diponegoro \\ *Email : erystarr@gmail.com
}

\begin{abstract}
The characteristics of society in choosing contraceptive methods are also the crucial factors for the government to prepare the family planning services needed at Bulakamba District, Brebes Regency, Central Java. In this case, a classification process needs to be done to assist the process of classifying the characteristics of society in the selection of contraceptive methods. Multinomial Logistic Regression classification is good in exploring data information meanwhile Fuzzy K Nearest Neighbor (FK-NN) classification is good for handling big data and noise. These two methods used in this study because they are relevant to the data applied and will be compared their classification accuracy through APER and Press's Q calculations.The classification accuracy results obtained based on the APER calculation for Multinomial Logistic Regression is 88,25\% and Fuzzy K Nearest Neighbor (FK-NN) is 88,92\%. Meanwhile, the Press's Q value of both methods are 9600,945 and 9518,014 greater than $\chi_{\alpha, 1}^{2}$ which is 3,841 , so that it is statistically accurate. Based on the results obtained, it can be concluded that Multinomial Logistic Regression classification method has a better classification accuracy than Fuzzy K Nearest Neighbor (FK-NN) method.
\end{abstract}

Keywords: Contraceptive Methods, Multinomial Logistic Regression, FKNN, APER, Press's Q.

\section{PENDAHULUAN}

Program Keluarga Berencana merupakan program skala nasional yang dikelola oleh Badan Kependudukan dan Keluarga Berencana Nasional (BKKBN) untuk mengendalikan pertambahan jumlah penduduk dan menekan angka kelahiran di Indonesia. Sejalan dengan terus berkembangannya Program KB yang dilaksanakan, pemerintah juga masih terus meningkatkan kualitas pelayanan KB untuk menunjang daya tarik masyarakat pada Program Keluarga Berencana tersebut salah satunya dengan menjamin ketersediaan alat/metode kontrasepsi. Karakteristik masyarakat dalam pemilihan metode kontrasepsi merupakan faktor penting bagi pemerintah untuk mempersiapkan pelayanan KB yang dibutuhkan di suatu daerah. Sehingga hal ini memunculkan peluang untuk dilakukannya proses klasifikasi guna membentuk ukuran ukuran yang baku dalam pengelompokan dan pendefinisian karekteristik masyarakat dalam pemilihan metode kontrasepsi.

Klasifikasi merupakan metode penelitian ketika suatu objek data dinilai untuk dimasukkan ke dalam suatu kelas tertentu dari sejumlah kelas yang ada atau tersedia (Prasetyo, 2012). Terdapat beberapa metode klasifikasi yang dapat digunakan dalam proses klasifikasi, diantaranya Regresi Logistik Multinomial dan Fuzzy K Nearest Neighbor (FKNN). Regresi Logistik Multinomial merupakan Regresi Logistik yang digunakan ketika variabel responnya memiliki skala yang bersifat polychotomus (Hosmer dan Lemeshow, 2000). Sedangkan Fuzzy K Nearest Neighbor (FK-NN) merupakan hasil perbaikan dari metode K Nearest Neighbor (K-NN). Perbaikan yang dilakukan oleh Fuzzy 7 K-Nearest Neighbor (FK-NN) yaitu dengan menggabungkan konsep tetangga terdekat dan teorema Fuzzy dalam menyampaikan definisi pemberian label kelas pada kelas data uji yang diprediksi (Prasetyo, 2012).

Beberapa penelitian sebelumnya yang dijadikan referensi dalam penelitian ini yaitu penelitian dari Kristiani dkk (2015), yang mengaplikasikan Multivariate Adaptive Regression Spline (MARS) dan Fuzzy K-Nearest Neighbor (FK-NN) pada data kelompok 
rumah tangga di Kabupaten Blora. Kesimpulan yang memperoleh yaitu ketepatan klasifikasi Fuzzy K-Nearest Neighbor (FK-NN) lebih baik dibandingkan metode Multivariate Adaptive Regression Spline (MARS). Selanjutnya penelitian oleh Puspita dkk (2014) dengan mengaplikasikan metode Regresi Logistik Ordinal dan Fuzzy K-Nearest Neighbor pada Tingkat Keluarga Sejahtera yang menghasilkan kesimpulan bahwa ketepatan klasifikasi dengan menggunakan Fuzzy K-Nearest Neighbor (FK-NN) lebih baik daripada klasifikasi Regresi Logistik Ordinal. Dari referensi tersebut, dalam penelitian ini dilakukan analisis Regresi Logistik Multinomial dan Fuzzy K-Nearest Neighbor (FK-NN) jika diaplikasikan pada kasus data pemilihan metode kontasepsi di Kecamatan Bulakamba, Kabupaten Brebes, Jawa Tengah. Kedua metode klasifikasi tersebut dibandingkan ketepatan klasifikasinya melalui perhitungan APER dan Press's Q untuk mengetahui metode klasifikasi yang memiliki performa lebih baik dalam pengelompokan dan pendefinisian karakteristik pemilihan metode kontrasepsi di Kecamatan Bulakamba, Kabupaten Brebes, Jawa Tengah.

\section{TINJAUAN PUSTAKA}

\subsection{Metode Kontrasepsi}

Metode kotrasepsi memiliki peranan penting dalam meningkatkan pelayanan dan daya tarik masyarakat terhadap Program Keluarga Berencana. Menurut Peraturan No. 24 Tahun 2017 metode kontrasepsi secara umum dikelompokkan menjadi 8 jenis, yaitu metode operasi wanita (MOW), metode operasi pria (MOP), IUD (Intrauterine Device), implan, suntik, pil, kondom, dan tradisional.

\subsection{Regresi Logistik Multinomial}

Analisis Regresi Logistik Multinomial merupakan Regresi Logistik yang digunakan ketika variabel respon mempunyai skala yang bersifat polychotomus atau multinomial (Hosmer dan Lemeshow, 2000). Sedangkan variabel prediktor pada analisis Regresi Logistik Multinomial bisa berupa data kategorik maupun numerik.

\subsubsection{Pembentukan Model}

Secara umum model Regresi Logistik Multinomial dengan $\mathrm{p}$ merupakan variabel prediktor dapat dituliskan sebagai berikut :

$$
\pi(x)=\frac{e^{\beta_{0}+\beta_{1} x_{1}+\cdots+\beta_{p} x_{p}}}{1+e^{\beta_{0}+\beta_{1} x_{1}+\cdots+\beta_{p} x_{p}}}
$$

Dengan $\pi(x)$ merupakan peluang kejadian dari y jika diberikan nilai $\mathrm{x}$, dan y merupakan variabel respon yang bersifat kategorik serta $\mathrm{x}$ merupakan variabel prediktor. Untuk mempermudah pendugaan parameter maka digunakan transformasi logit dari $\pi(x)$ yang kemudian menghasilkan persamaan baru sebagai berikut :

$$
g(x)=\ln \left\{\frac{\pi(x)}{1-\pi(x)}\right\}=\beta_{0}+\beta_{1} x_{1}+\cdots+\beta_{p} x_{p}
$$

Dari persamaan (2), model Regresi Logistik pada persamaan (1) dapat dituliskan secara lebih sederhana seperti berikut :

$$
\pi(x)=\frac{e^{g(x)}}{1+e^{g(x)}}
$$

\subsubsection{Estimasi Parameter}

Dalam menentukan estimasi parameter dari Regresi Logistik Multinomial digunakan metode Maksimum Likelihood yang selanjutnya akan diselesaikan dengan metode Iterasi Newton Raphson. Misalkan sebuah variabel respon memiliki 3 kategori yaitu $\mathrm{j}=0,1,2$, maka fungsi likelihood untuk sebuah sampel dari $\mathrm{n}$ pengamatan secara independen adalah sebagai berikut :

$$
l(\beta)=\prod_{i=1}^{n} \pi_{0}\left(x_{i}\right)^{y_{0 i}} \pi_{1}\left(x_{i}\right)^{y_{1 i}} \pi_{2}\left(x_{i}\right)^{y_{2 i}}
$$


Dari persamaan (4) kemudian dibentuk fungsi ln-likelihood sebagai berikut :

$$
L(\beta)=\sum_{i=1}^{n} y_{1_{i}} g_{1}\left(x_{i}\right)+y_{2_{i}} g_{2}\left(x_{i}\right)-\ln \left(1+e^{g_{1}\left(x_{i}\right)}+e^{g_{2}\left(x_{i}\right)}\right)
$$

Dari persamaan (5) kemudian didapatkan bentuk umum turunan pertamanya sebagai berikut:

$$
\frac{\partial L(\beta)}{\partial \beta_{j 0}}=\sum_{i=1}^{n}\left[y_{j i}-\pi_{j}\left(x_{i}\right)\right] \quad \text { (6) } \quad \frac{\partial L(\beta)}{\partial \beta_{j k}}=\sum_{i=1}^{n} x_{k i}\left[y_{j i}-\pi_{j}\left(x_{i}\right)\right]
$$

Hasil turunan pertama dapat dinyatakan dalam bentuk matrik $\boldsymbol{M}(\boldsymbol{Y}-\boldsymbol{\pi}(\boldsymbol{x}))$, dengan penjabaran (untuk 3 kategori) :

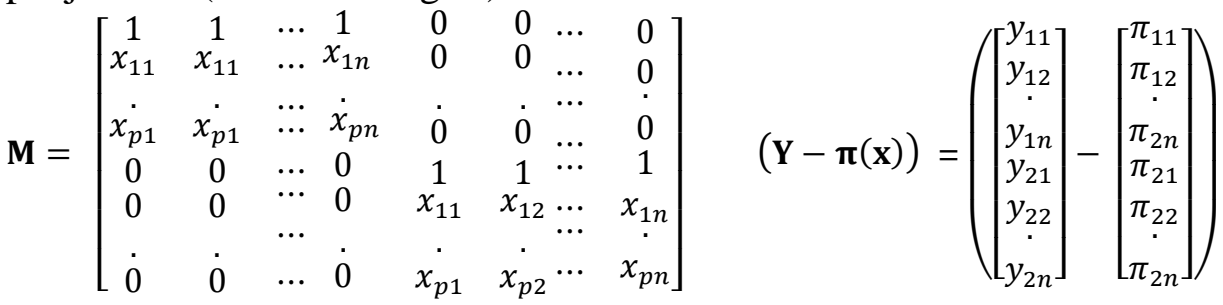

Hasil turunan pertama tidak berbentuk close form, maka dilanjutkan dengan iterasi Newton Raphson.Bentuk umum turunan kedua dapat dituliskan melalui persamaan berikut :

$\frac{\partial^{2} L(\beta)}{\partial \beta_{j k} \partial \beta_{j k}}=-\sum_{i=1}^{n} x_{k i} x_{k i} \pi_{j}\left(x_{i}\right)\left[1-\pi_{j}\left(x_{i}\right)\right]$

$\frac{\partial^{2} L(\beta)}{\partial \beta_{j k} \partial \beta_{j k}}=-\sum_{i=1}^{n} x_{k i} x_{k i} \pi_{j}\left(x_{i}\right) \pi_{j}\left(x_{i}\right)$

Misalkan $\hat{\boldsymbol{\imath}}(\widehat{\boldsymbol{\beta}})$ adalah matrik yang berukuran $p x p$ dari persamaan (8) dan (9) yang bernilai negatif.

$$
\hat{\boldsymbol{\imath}}(\widehat{\boldsymbol{\beta}})=\left[\begin{array}{ll}
\hat{\imath}(\hat{\beta})_{11} & \hat{\imath}(\hat{\beta})_{12} \\
\hat{\imath}(\hat{\beta})_{21} & \hat{\imath}(\hat{\beta})_{22}
\end{array}\right]
$$

Dengan : $\hat{\imath}(\hat{\beta})_{11}=\boldsymbol{X}^{\prime} \boldsymbol{V}_{\mathbf{1}} \boldsymbol{X} \quad \hat{\imath}(\hat{\beta})_{12}=\hat{\imath}(\hat{\beta})_{21}=\boldsymbol{X}^{\prime} \boldsymbol{V}_{\mathbf{3}} \boldsymbol{X} \quad \hat{\imath}(\hat{\beta})_{22}=\boldsymbol{X}^{\prime} \boldsymbol{V}_{\mathbf{2}} \boldsymbol{X}$

dan $\mathbf{V}_{\mathbf{j}}$ merupakan matrik diagonal $n \times n$ dengan elemen umum $\pi_{j}\left(x_{i}\right)\left[1-\pi_{j}\left(x_{i}\right)\right]$, untuk $\mathbf{j}$ $=1,2$ dan $\mathrm{i}=1,2,3, \ldots ., \mathrm{n}$. Untuk $\mathbf{V}_{\mathbf{3}}$ merupakan matrik diagonal $n \times n$ dengan elemen umum $\pi_{1}\left(x_{i}\right) \pi_{2}\left(x_{i}\right)$. Selanjutnya akan diselesaikan dengan metode Iterasi Newton Raphson dengan langkah langkah sebagai berikut :

1. Memilih taksiran awal untuk $\boldsymbol{\beta}$, dimisalkan $\widehat{\boldsymbol{\beta}}=0$

2. Menghitung $\mathbf{M}(\mathbf{Y}-\boldsymbol{\pi}(\mathbf{x}))$ dan $\hat{\boldsymbol{\imath}}(\widehat{\boldsymbol{\beta}})$, selanjutnya dihitung invers dari $\hat{\boldsymbol{\imath}}(\widehat{\boldsymbol{\beta}})$

3. Pada setiap $\mathrm{t}+1$ dihitung taksiran baru yaitu

$$
\widehat{\boldsymbol{\beta}}^{(t+1)}=\widehat{\boldsymbol{\beta}}^{(t)}+\hat{\boldsymbol{\imath}}(\widehat{\boldsymbol{\beta}})^{-\mathbf{1}}\{\mathbf{M}(\mathbf{Y}-\boldsymbol{\pi}(\mathbf{x}))\}
$$

4. Iterasi berakhir jika diperoleh $\left|\widehat{\boldsymbol{\beta}}^{(\boldsymbol{t}+\mathbf{1})}\right| \cong\left|\widehat{\boldsymbol{\beta}}^{(\boldsymbol{t})}\right|$

\subsubsection{Pengujian Parameter}

1) Uji Parameter secara Keseluruhan

Uji Rasio Likelihood merupakan uji signifikansi parameter secara keseluruhan atau bersama-sama (Hosmer dan Lemeshow,2000).

Hipotesis :

$\mathrm{H}_{0}: \beta_{j k}=0$ (Tidak ada pengaruh antara variable prediktor terhadap variabel respon dengan $j=1,2, \ldots, r-1$ dan $k=1,2, . ., p$ )

$\mathrm{H}_{1}$ : Paling sedikit ada satu $\beta_{j k} \neq 0$, dengan $j=1,2, \ldots, r-1$ dan $k=1,2, . ., p$

(Paling sedikit ada satu variabel prediktor yang berpengaruh terhadap variabel respon)

Statistik uji $: G^{2}=-2 \ln \left[\frac{\text { likelihood tanpa variabel bebas }}{\text { likelihood dengan variabel bebas }}\right]$

Kriteria penolakan : Tolak $\mathrm{H}_{0}$ apabila $\mathrm{G}^{2}>\chi^{2}\left({ }_{(\alpha: \mathrm{db})}\right.$ dengan derajad bebas yang digunakan yaitu sebesar banyaknya variabel predictor. 
2) Uji Parameter secara Parsial

Bewick dkk (2005) mengatakan bahwa uji Wald digunakan untuk menguji signifikansi koefisien parameter secara individual dalam suatu model.

Hipotesis :

$\mathrm{H}_{0}: \beta_{j k}=0$, (Tidak ada pengaruh variabel prediktor ke-jk terhadap variabel respon, dengan $j=1,2, \ldots, r-1$ dan $k=1,2, \ldots, p$ )

$\mathrm{H}_{1}: \beta_{j k} \neq 0$, (Ada pengaruh variabel prediktor ke-jk terhadap variabel respon, dengan $j=1,2, \ldots, r-1$ dan $k=1,2, \ldots, p$ )

Statistik uji $: W_{\mathrm{jk}}=\left\{\frac{\widehat{\beta}_{\mathrm{jk}}}{\operatorname{SE}\left(\widehat{\beta}_{\mathrm{jk}}\right)}\right\}^{2} \quad$ (13) $\quad \mathrm{SE}\left(\widehat{\beta}_{\mathrm{jk}}\right)=\sqrt{\left(\sigma^{2}\left(\widehat{\beta}_{\mathrm{jk}}\right)\right)}$

Dengan $\operatorname{SE}\left(\widehat{\beta}_{\mathrm{jk}}\right)$ merupakan dugaan kesalahan baku dari koefisien $\beta_{\mathrm{jk}}$ dan $\widehat{\beta}_{\mathrm{jk}}$.

Kriteria penolakan : Tolak $\mathrm{H}_{0}$ apabila $\mathrm{W}_{\mathrm{jk}}>\chi_{(\alpha: 1)}^{2}$.

\subsubsection{Uji Kesesuaian Model}

Uji kesesuaian model digunakan untuk menguji kelayakan suatu model yang telah terbentuk.

Hipotesis :

$\mathrm{H}_{0}$ : Model sesuai (Tidak ada perbedaan antara hasil pengamatan dengan hasil prediksi)

$\mathrm{H}_{1}$ : Model tidak sesuai (Ada perbedaan antara hasil pengamatan dengan hasil prediksi)

Statistik uji : ${ }_{-} \hat{C}=\sum_{i=1}^{k} \frac{\left(O_{i}-n_{i} \overline{\pi_{l}}\right)^{2}}{n_{i} \overline{\pi_{l}}\left(1-\overline{\pi_{l}}\right)}$

Dengan keterangan sebagai berikut :

$O_{i} \quad$ : Pengamatan pada kelompok ke-i

$k \quad:$ Jumlah kelompok (kombinasi kategori) dalam model serentak

$\mathrm{n}_{\mathrm{i}} \quad$ : Banyaknya pengamatan pada kelompok ke-i

$\bar{\pi}_{l} \quad$ : Rata-rata taksiran peluang pengamatan kelompok ke-i

Kriteria penolakan : Tolak $\mathrm{H}_{0}$ apabila nilai $\hat{C}>\chi^{2}(\alpha: \mathrm{db})$, dengan derajad bebas yang digunakan yaitu $\mathrm{db}=(\mathrm{k}-2)$.

\subsubsection{Proses Klasifikasi}

Dalam penentuan hasil prediksi dari suatu data uji maka harus dilihat besar estimasi probabilitas dari data tersebut pada setiap kategorinya. Kategori yang memiliki nilai estimasi probabilitas tertinggi akan dipilih sebagai kelas prediksi dari suatu data uji.

\subsection{Fuzzy K-Nearest Nieghbor (FK-NN)}

Dalam algoritma Fuzzy K-Nearest Neighbor (FK-NN) pengukuran nilai jarak antara data latih dan data uji pada data rasio/interval dapat digunakan rumus jarak Euclidean yang diformulasikan sebagai berikut (Li dkk, 2007) :

$$
d\left(x_{i}, x_{h}\right)=\left(\sum_{l=1}^{L}\left|x_{i l}-x_{h l}\right|^{2}\right)^{\frac{1}{2}}
$$

Dengan : $d\left(x_{i}, x_{h}\right)=$ jarak antara data $x_{i}$ ke data $x_{h} ; \mathrm{L}=$ banyaknya variabel prediktor

Sedangkan pada data bersifat kategorik nominal, perhitungan jaraknya dapat menggunakan formula berikut :

$$
d_{\text {nom }}=\left\{\begin{array}{llll}
0 & \text { jika } & x_{i l}=x_{h l} \\
1 & j i k a & x_{i l} \neq x_{h l}
\end{array}\right.
$$

Dengan : $d_{\text {nom }}=$ jarak untuk kasus data nominal

$x_{i l}=$ data latih ke-i pada variabel prediktor ke-1

$x_{h l}=$ data uji ke-h pada variabel prediktor ke-l

Pengukuran jarak untuk kasus data variabel kategorik bersifat ordinal yaitu dengan menggunakan formula berikut: 


$$
\left(x_{f l}\right)_{b a r u}=\frac{R_{f l}-1}{M_{l}-1}
$$

Dengan : $\left(x_{f l}\right)_{b a r u}=$ data ke-f hasil tranformasi pada variabel prediktor ke-l.

$R_{f l} \quad=$ rangking data ke-f pada variabel ke-l.

$M_{l} \quad=$ total kategori pada variabel ke -1 .

Nilai jarak Euclidean antara data latih dan data uji diurutkan dari yang terkecil dan diambil sebanyak K jarak terkecil untuk kemudian menjadi data tetangga yang disebut $x_{k}$, dimana $\mathrm{k}=1,2, \ldots, \mathrm{K}$. Nilai keanggotaan data tetangga $x_{k}$ ke kelas $c_{j}$ dapat diformulasikan sebagai berikut :

$$
u\left(x_{k}, c_{j}\right)= \begin{cases}0 & \text { jika } \mathrm{x}_{\mathrm{k}} \text { bukan milik kelas } \mathrm{c}_{\mathrm{j}} \\ 1 & \text { jika } \mathrm{x}_{\mathrm{k}} \text { milik kelas } \mathrm{c}_{\mathrm{j}}\end{cases}
$$

Menurut Li dkk (2007), formula untuk mencari nilai keanggotaan data uji $x_{i}$ kedalam kelas $c_{j}$ dapat dituliskan sebagai berikut :

$$
u\left(x_{i}, c_{j}\right)=\frac{\sum_{k=1}^{K}\left[u\left(x_{k}, c_{j}\right)\right] \times\left[d\left(x_{i}, x_{k}\right)^{\frac{-2}{(m-1)}}\right]}{\sum_{k=1}^{K} d\left(x_{i}, x_{k}\right)^{\frac{-2}{(m-1)}}}
$$

Dengan keterangan sebagai berikut :

$$
\begin{array}{ll}
c_{j} & : \text { kelas/kelompok ke-j, dengan } 1 \leq j \leq C \\
\mathrm{C} & : \text { banyaknya kelas/kelompok } \\
x_{i} & : \text { data uji ke-i } \\
x_{k} & : \text { data tetangga ke-k dalam K tetangga terdekat } \\
u\left(x_{i}, c_{j}\right) & : \text { nilai keanggotaan data uji } x_{i} \text { kedalam kelas } c_{j} . \\
\mathrm{K} & : \text { banyaknya tetangga terdekat yang digunakan } \\
u\left(x_{k}, c_{j}\right) & : \text { nilai keanggotaan dari data tetangga } x_{k} \text { dalam K tetangga terdekat } \\
& \text { pada kelas } c_{j} \text { yang dapat dicari dengan meggunakan persamaan } \\
& \text { (19). } \\
d\left(x_{i}, x_{k}\right) & : \text { jarak Euclidean dari data } x_{i} \text { terhadap data } x_{k} \text { dalam K tetangga } \\
& \text { terdekat. } \\
\mathrm{m} & \text { : pembobot pangkat, dengan besar } \mathrm{m}>1 \text {. Pembobot m ditentukan } \\
& \text { sesuai dengan banyaknya kelas yang terbentuk dalam klasifikasi } \\
& \text { atau kategori variabel dependen yang telah ditetapkaan. }
\end{array}
$$

Konsep kerja algoritma Fuzzy K-Nearest Neighbor (FK-NN) yaitu sebagai berikut :

1.) Menentukan $\mathrm{K}$ tetangga terdekat dengan perhitungan jarak Euclidean pada persamaan (16). $\mathrm{K}$ yang digunakan dalam penelitian ini yaitu $\mathrm{K}=1,2, \ldots, 15$.

2.) Menghitung nilai keanggotaan data uji pada setiap kelas dengan persamaan (20).

3.) Kelas dengan nilai keanggotaan data terbesar akan terpilih menjadi label kelas pada data uji, atau dapat dituliskan dengan formula berikut (Prasetyo, 2012):

$$
y^{\prime}=\operatorname{ArgMax}_{j=1}^{C}\left(u\left(x_{i}, c_{j}\right)\right)
$$

\subsection{Ketepatan Klasifikasi}

Nilai APER berfungsi untuk menghitung nilai proporsi sampel yang salah diklasifikasikan dalam proses klasifikasi (Johnson dan Winchern, 2007). Nilai APER dapat dihitung dengan menggunakan rumus berikut :

$$
\begin{aligned}
& A P E R=\frac{\text { proporsi pengamatan yang terklasifikasikan salah }}{\text { total pengamatan }} \\
& \text { Ketepatan klasifikasi }=1-A P E R
\end{aligned}
$$


Semakin tinggi nilai ketepatan klasifikasi yang dihasilkan maka semakin baik pula keefektifan metode klasifikasi tersebut dalam mengelompokan suatu objek. Sedangkan Statistik uji dari Press's $Q$ dapat dirumuskan sebagai berikut :

$$
\operatorname{Press}^{\prime} S Q=\frac{[N-(r C)]^{2}}{N(C-1)}
$$

Dengan : $\mathrm{C}=$ banyaknya kelas/kelompok

$\mathrm{N}=$ banyaknya pengamatan secara keseluruhan

$\mathrm{r}=$ banyaknya pengamatan yang terklasifikasikan secara tepat

Proses klasifikasi akan dikatakan akurat secara statistik apabila nilai Press's $Q$ lebih besar dari pada nilai kritis yang diambil dari tabel Chi-Square dengan derajat bebas bernilai 1 dan tingkat keyakinan sebesar $\alpha$ (Press's $\left.Q>\chi_{\alpha, 1}^{2}\right)$.

\section{METODE PENELITIAN}

\subsection{Jenis dan Sumber Data}

Jenis data yang digunakan dalam penelitian ini adalah data sekunder, yaitu data pemilihan metode kontrasepsi oleh PUS yang sedang menjalankan Program KB di Kabupaten Brebes, Kecamatan Bulakamba yang dapat diakses melalui website resmi Badan Kependudukan dan Keluarga Berencana Nasional (BKKBN) Jawa Tengah dengan alamat : http://pk.bkkbn.go.id/pk/Peralatan/UnduhFormulirDataKeluarga.aspx.

\subsection{Variabel Penelitian}

Variabel yang digunakan dalam penelitia ini yaitu sebagai berikut :

Tabel 1. Variabel Penelitian

\begin{tabular}{|c|c|}
\hline Nama Variabel & Kategori \\
\hline \multicolumn{2}{|l|}{ Variabel Respon (Y) } \\
\hline Metode Kontrasepsi (Y) & $\begin{array}{l}\text { 1= IUD ; } 2=\text { MOP ; } 3=\text { Suntik ; } 4=\text { Kondom; } 5=\text { MOW ; } \\
6=\text { Implant } ; 7=\text { Pil } ; 8=\text { Tradisional. }\end{array}$ \\
\hline \multicolumn{2}{|l|}{ Variabel Prediktor (X) } \\
\hline Usia Suami (X1) & $\begin{array}{l}1=\text { Umur }<20 \text { tahun } ; 2=20 \leq \text { Umur } \leq 35 \text { tahun } ; \\
3=\text { Umur }>35 \text { tahun }\end{array}$ \\
\hline Usia Istri (X2) & $\begin{array}{l}1=\text { Umur }<20 \text { tahun } ; 2=20 \leq \text { Umur } \leq 35 \text { tahun } ; \\
3=\text { Umur }>35 \text { tahun }\end{array}$ \\
\hline $\begin{array}{l}\text { Usia Kawin Pertama } \\
\text { Suami (X3) }\end{array}$ & $1=$ Umur $\leq 25$ tahun $; 2=$ Umur $>25$ tahun \\
\hline $\begin{array}{l}\text { Usia Kawin Pertama Istri } \\
\text { (X4) }\end{array}$ & $1=$ Umur $\leq 20$ tahun $; 2=$ Umur $>20$ tahun \\
\hline $\begin{array}{l}\text { Jumlah Anak Masih Hidup } \\
\text { (X5) }\end{array}$ & $1=$ Jumlah anak hidup $\leq 2$ anak $; 2=$ Jumlah anak hidup $>2$ anak \\
\hline Pendidikan Suami (X6) & $\begin{array}{l}1=\text { Tidak sekolah } ; 2=\text { Tamat SD/MI } ; 3=\text { Tamat SMP/MTs } ; 4 \\
=\text { Tamat SMA/Mta } ; 5=\text { Tamat PT/Akademi }\end{array}$ \\
\hline Pekerjaan Suami (X7) & $\begin{array}{l}1=\text { Tidak bekerja } ; 2=\text { Kelompok pekerjaan tidak terampil } ; 3= \\
\text { Kelompok pekerjaan terampil }\end{array}$ \\
\hline Pendidikan Istri (X8) & $\begin{array}{l}1=\text { Tidak sekolah } ; 2=\text { Tamat SD/MI } ; 3=\text { Tamat SMP/MTs } ; 4 \\
=\text { Tamat SMA/Mta } ; 5=\text { Tamat PT/Akademi }\end{array}$ \\
\hline Pekerjaan Istri (X9) & $\begin{array}{l}1=\text { Tidak bekerja } ; 2=\text { Kelompok pekerjaan tidak terampil } ; 3= \\
\text { Kelompok pekerjaan terampil }\end{array}$ \\
\hline JKN Suami (X10) & $1=$ Tidak Memiliki $; 2=$ Memiliki \\
\hline JKN Istri (X11) & 1 = Tidak Memiliki $; 2$ = Memiliki \\
\hline Tempat Pelayanan (X12) & $\begin{array}{l}1=\text { Lainnya (Penanganan pribadi) } ; 2=\text { Fasilitas kesehatan } \\
\text { tingkat pertama } / \text { FKTP } ; 3=\text { Fasilitas kesehatan tingkat lanjut } / \\
\text { FKTL }\end{array}$ \\
\hline
\end{tabular}




\begin{tabular}{|l|l|}
\hline $\begin{array}{l}\text { Ingin Punya Anak Lagi } \\
(\mathrm{X} 13)\end{array}$ & $1=$ Tidak ingin memiliki anak lagi ; 2 = Ingin memiliki anak lagi \\
\hline
\end{tabular}

\subsection{Tahapan Pengolahan Data}

Software yang digunakan dalam pengolahan penelitian ini adalah Program R versi 4.0.2 dan MATLAB 2015a. Tahapan analisis pada penelitian Tugas Akhir ini dibagi menjadi 2 langkah utama yang diuraikan sebagai berikut :

1) Menentukan faktor faktor yang mempengaruhi dengan metode Regresi Logistik Multiomial. Tahapan yang dilakukan yaitu pembentukan model awal, melakukan uji serentak dengan uji Rasio Likelihood, melakukan uji parsial dengan uji Wald dan kesimpulan.

2) Melakukan klasifikasi dengan menggunakan metode Regresi Logistik Multinomial dan Fuzzy K Nearest Neighbor (FK-NN).

(a) Input data.

(b) Membagi data menjadi data latih dan data uji. Perbandingan data latih dan data uji yang dipilih yaitu $90 \%: 10 \%$.

(c) Klasifikasi dengan menggunakan metode Regresi Logistik Multinomial.

- Pembentukan model klasifikasi dengan data latih.

- Melakukan uji serentak dengan uji Rasio Likelihood.

- Melakukan uji parsial dengan uji Wald.

- Melakukan uji kesesuaian model.

- Menentukan model akhir.

- Pembentukan estimasi probabilitas

- Melakukan klasifikasi menggunakan data uji untuk membentuk hasil prediksi.

- Menghitung ketepatan klasifikasi menggunakan Press's $Q$ dan APER.

(d) Klasifikasi dengan menggunakan Fuzzy K Nearest Neighbor (FK-NN).

- Menentukan K tetangga terdekat untuk data uji $\mathrm{x}_{\mathrm{i}}$.

- Menghitung nilai $u\left(x_{i}, c_{j}\right)$ atau nilai keanggotaan data uji $x_{i}$ ke kelas $c_{j}$.

- Menentukan nilai keanggotaan terbesar dari data uji $x_{i}$ ke kelas $c_{j}\left(u\left(x_{i}, c_{j}\right)\right)$.

- Membentuk matrik konfunsi dan menghitung ketepatan klasifikasinya menggunakan Press's $Q$ dan APER.

(e) Melakukan perbandingan nilai ketepatan klasifikasi antara kedua metode (Regresi Logistik Multinomial dan Fuzzy K Nearest Neighbor (FK-NN)) menggunakan nilai Press's $Q$ dan APER.

(f) Intepretasi hasil dan kesimpulan.

\section{HASIL DAN PEMBAHASAN}

\subsection{Menentukan Faktor Faktor yang Mempengaruhi Pemilihan Metode Kontrasepsi} dengan Regresi Logistik Multinomial

\subsubsection{Model Tahap Pertama}

Pembentukan model tahap pertama Regresi Logistik Multinomial dilakukan menggunakan variabel respon yaitu jenis metode kontrasepsi (Y) dan variabel prediktor yaitu X1, X2, X3, X4, X5, X6, X7, X8, X9, X10, X11, X12, dan X13. Kategori suntik (Y(3)) pada variabel respon dijadikan sebagai kategori baseline. Hasil uji Rasio Likelihood yang diperoleh yaitu sebagai berikut : 
Tabel 2. Output Uji Rasio Likelihood Tahap 1

\begin{tabular}{cccc}
\hline Ilh & llhNull & $\mathbf{G}^{2}$ & $\boldsymbol{\chi}^{\mathbf{2}(\mathbf{0 , 0 5 : 1 3 )}}$ \\
\hline$-8682,785$ & $-10583,45$ & 3801,323 & 22,362 \\
\hline
\end{tabular}

Berdasarkan Tabel 2 diatas, karena nilai $\mathrm{G}^{2}=3801,323>X^{2}(0,05: 13)=22,362$ sehingga $H_{o}$ ditolak, yang artinya paling sedikit ada satu variabel prediktor yang berpengaruh terhadap variabel respon. Sedangkan hasil uji Wald yang diperoleh yaitu sebagai berikut :

Tabel 3. Hasil Uji Wald Regresi Logistik Multinomial Tahap 1

\begin{tabular}{|c|l|l|}
\hline $\begin{array}{c}\text { Variabel } \\
\text { Prediktor }\end{array}$ & \multicolumn{1}{|c|}{ Hasil Uji Wald } & \multicolumn{1}{c|}{ Kesimpulan } \\
\hline X1 & Ada koefisien yang signifikan & Berpengaruh terhadap model \\
\hline X2 & Ada koefisien yang signifikan & Berpengaruh terhadap model \\
\hline X3 & Ada koefisien yang signifikan & Berpengaruh terhadap model \\
\hline X4 & Ada koefisien yang signifikan & Berpengaruh terhadap model \\
\hline X5 & Ada koefisien yang signifikan & Berpengaruh terhadap model \\
\hline X6 & Ada koefisien yang signifikan & Berpengaruh terhadap model \\
\hline X7 & Ada koefisien yang signifikan & Berpengaruh terhadap model \\
\hline X8 & Ada koefisien yang signifikan & Berpengaruh terhadap model \\
\hline X9 & Ada koefisien yang signifikan & Berpengaruh terhadap model \\
\hline X10 & Tidak ada koefisien yang signifikan & Tidak berpengaruh terhadap model \\
\hline X11 & Tidak ada koefisien yang signifikan & Tidak berpengaruh terhadap model \\
\hline X12 & Ada koefisien yang signifikan & Berpengaruh terhadap model \\
\hline X13 & Ada koefisien yang signifikan & Berpengaruh terhadap model \\
\hline
\end{tabular}

\subsubsection{Model Tahap Kedua}

Berdasarkan Tabel 3, karena variabel X10 dan X11 tidak berpengaruh terhadap model tahap pertama sehingga dilakukan pengujian kembali tanpa mengikutsertakan kedua variabel tersebut. Model baru yang terbentuk disebut model tahap 2. Pengujian parameter secara keseluruhan terhadap model tahap 2 diperoleh hasil sebagai berikut :

Tabel 4. Output Uji Rasio Likelihood Tahap 2

\begin{tabular}{cccc}
\hline llh & llhNull & $\mathbf{G}^{\mathbf{2}}$ & $\boldsymbol{\chi}^{\mathbf{2}(\mathbf{0 , 0 5 : 1 1 )}}$ \\
\hline$-8667,668$ & $-10583,45$ & 3831,558 & 19,675 \\
\hline
\end{tabular}

Berdasarkan Tabel 4 diatas, karena nilai $G^{2}=3831,558>X^{2}(0,05: 13)=19,675$ sehingga $H_{o}$ ditolak, yang artinya paling sedikit ada satu variabel prediktor yang berpengaruh terhadap variabel respon. Selanjutnya pada uji Wald terhadap model tahap 2 diperoleh hasil sebagai berikut :

Tabel 5. Hasil Uji Wald Regresi Logistik Multinomial Tahap 2

\begin{tabular}{|c|l|l|}
\hline $\begin{array}{c}\text { Variabel } \\
\text { Prediktor }\end{array}$ & \multicolumn{1}{|c|}{ Hasil Uji Wald } & \multicolumn{1}{c|}{ Kesimpulan } \\
\hline $\mathrm{X} 1$ & Ada koefisien yang signifikan & Berpengaruh terhadap model \\
\hline $\mathrm{X} 2$ & Ada koefisien yang signifikan & Berpengaruh terhadap model \\
\hline $\mathrm{X} 3$ & Ada koefisien yang signifikan & Berpengaruh terhadap model \\
\hline
\end{tabular}




\begin{tabular}{|l|l|l|} 
X4 & Ada koefisien yang signifikan & Berpengaruh terhadap model \\
\hline X5 & Ada koefisien yang signifikan & Berpengaruh terhadap model \\
\hline X6 & Ada koefisien yang signifikan & Berpengaruh terhadap model \\
\hline X7 & Ada koefisien yang signifikan & Berpengaruh terhadap model \\
\hline X8 & Ada koefisien yang signifikan & Berpengaruh terhadap model \\
\hline X9 & Ada koefisien yang signifikan & Berpengaruh terhadap model \\
\hline X12 & Ada koefisien yang signifikan & Berpengaruh terhadap model \\
\hline X13 & Ada koefisien yang signifikan & Berpengaruh terhadap model \\
\hline
\end{tabular}

Berdasarkan analisis diatas sehingga dapat disimpulkan bahwa variabel prediktor yang mempengaruhi pemilihan metode kontrasepsi masyarakat Kecamatan Bulakamba yaitu X1,X2, X3, X4, X5, X6, X7, X8, X9, X12, dan X13. Selanjutnya akan dilakukan klasifikasi menggunakan variabel prediktor tersebut.

\subsection{Proses Klasifikasi}

\subsubsection{Pembagian Data}

Pembagian data dilakukan dengan Program $\mathrm{R}$ dan diperoleh hasil bahwa dari total data sebesar 18543 jenis pemilihan metode kontrasepsi, akan digunakan 16713 data sebagai data latih dan 1830 sebagai data uji.

\subsubsection{Klasifikasi Regresi Logistik Multinomial}

1) Pembentukan Model

Pembentukan model klasifikasi dilakukan dengan variabel prediktor yaitu X1, X2, X3, $\mathrm{X} 4, \mathrm{X} 5, \mathrm{X} 6, \mathrm{X} 7, \mathrm{X} 8, \mathrm{X} 9, \mathrm{X} 12$, dan X13. Kategori suntik (Y(3)) pada variabel respon dijadikan sebagai kategori baseline.

2) Pengujian Parameter

(a) Uji Parameter secara Keseluruhan

Hasil uji Rasio Likelihood yang diperoleh terhadap model klasifikasi yang terbentuk yaitu sebagai berikut :

Tabel 6. Output Uji Rasio Likelihood Klasifikasi Regresi Logistik Multinomial

\begin{tabular}{cccc}
\hline llh & llhNull & $\mathbf{G}^{\mathbf{2}}$ & $\boldsymbol{\chi}^{\mathbf{2}(\mathbf{0 , 0 5 : 1 1 )}}$ \\
\hline$-7821,465$ & $-9541,138$ & 3439,348 & 19.675 \\
\hline
\end{tabular}

Berdasarkan Tabel 6 diatas, karena nilai $\mathrm{G}^{2}=3439,348>X^{2}(0,05: 13)=19,675$ sehingga $\mathrm{H}_{\mathrm{o}}$ ditolak, yang artinya paling sedikit ada satu variabel prediktor yang berpengaruh terhadap variabel respon.

(b) Uji Parameter secara Parsial

Hasil uji Wald yang diperoleh terhadap model klasifikasi yaitu sebagai berikut :

Tabel 7. Hasil Uji Wald Klasifikasi Regresi Logistik Multinomial

\begin{tabular}{|c|l|l|}
\hline $\begin{array}{c}\text { Variabel } \\
\text { Prediktor }\end{array}$ & \multicolumn{1}{|c|}{ Hasil Uji Wald } & \multicolumn{1}{c|}{ Kesimpulan } \\
\hline $\mathrm{X} 1$ & Ada koefisien yang signifikan & Berpengaruh terhadap model \\
\hline $\mathrm{X} 2$ & Ada koefisien yang signifikan & Berpengaruh terhadap model \\
\hline $\mathrm{X} 3$ & Ada koefisien yang signifikan & Berpengaruh terhadap model \\
\hline $\mathrm{X} 4$ & Ada koefisien yang signifikan & Berpengaruh terhadap model \\
\hline $\mathrm{X} 5$ & Ada koefisien yang signifikan & Berpengaruh terhadap model \\
\hline
\end{tabular}




\begin{tabular}{|c|l|l|} 
X6 & Ada koefisien yang signifikan & Berpengaruh terhadap model \\
\hline X7 & Ada koefisien yang signifikan & Berpengaruh terhadap model \\
\hline X8 & Ada koefisien yang signifikan & Berpengaruh terhadap model \\
\hline X9 & Ada koefisien yang signifikan & Berpengaruh terhadap model \\
\hline X12 & Ada koefisien yang signifikan & Berpengaruh terhadap model \\
\hline X13 & Ada koefisien yang signifikan & Berpengaruh terhadap model \\
\hline
\end{tabular}

Berdasarkan analisis diatas dapat diketahui bahwa semua variabel prediktor yaitu X1, $\mathrm{X} 2, \mathrm{X} 3, \mathrm{X} 4, \mathrm{X} 5, \mathrm{X} 6, \mathrm{X} 7, \mathrm{X} 8, \mathrm{X} 9, \mathrm{X} 12$, dan X13 signifikan mempengaruhi model, sehingga model logit pada persamaan (26), (27), (28), (29), (30), (31), (32) dapat digunakan sebagai model akhir.

3) Kesesuaian Model

Hasil yang diperoleh dari uji kesesuaian model yaitu sebagai berikut :

Tabel 8. Output Uji Kesesuaian Model

\begin{tabular}{cccc}
\hline \multicolumn{4}{c}{ Hosmer and Lemeshow test } \\
\hline Chi-square & Df & $\chi^{\mathbf{2}{ }_{\text {tabel }}}$ & P-value \\
\hline 62,788 & 56 & 74,468 & 0,248
\end{tabular}

Bedasarkan Tabel 8 dapat disimpulkan bahwa $\mathrm{H}_{0}$ diterima karena nilai chi-square hitung yang diperoleh adalah 62,788 lebih kecil dari nilai $\chi^{2}$ tabel yaitu 74,468 dan nilai p-value yang diperoleh sebesar 0,248 yang artinya lebih besar dari $\alpha=0,05$. Hal tersebut menunjukan bahwa dengan tingkat keyakinan $95 \%$ model yang dihasilkan sesuai.

4) Hasil Prediksi

Hasil prediksi secara kumulatif untuk setiap jenis metode kontrasepsi (kategori) dapat dilihat pada tabel berikut :

Tabel 9. Hasil Prediksi Secara Kumulatif per Kategori

\begin{tabular}{ccccccccc}
\hline & \multicolumn{7}{c}{ Jenis Metode Kontrasepsi (Kategori) } \\
\cline { 2 - 10 } & IUD & MOP & Suntik & Kondom & MOW & Implant & Pil & Tradisional \\
Aktual & (Y1) & (Y2) & (Y3) & (Y4) & (Y5) & (Y6) & (Y7) & (Y8) \\
Prediksi & 7 & 5 & 1593 & 3 & 35 & 57 & 108 & 3 \\
\hline
\end{tabular}

5) Ketepatan Klasifikasi

Pada perhitugan ketepatan klasifikasi menggunakan Apparent Error Rate (APER) diperlukan sebuah matrik konfunsi untuk mengetahui jumlah data yang terklasifikasikan benar dan jumlah data yang terklasifikasikan salah. Hasil dari matrik konfunsi yang terbentuk yaitu sebanyak 1589 data terklasifikasikan benar dan 203 data terklasifikasikan salah. Nilai APER yang diperoleh dalam analisis ini yaitu sebesar 0,8825. Sedangkan nilai Press's Q diperoleh sebesar 9600,945.Berdasarkan hasil tersebut dapat diketahui bahwa nilai Press's $Q>\chi_{\alpha, 1}^{2}$ yaitu 3,841, sehingga dapat disimpulkan bahwa dengan tingkat keyakinan 95\% metode klasifikasi Regresi Logistik Multinomial akurat secara statistik.

\subsubsection{Klasifikasi Fuzzy K-Nearest Neighbor (FK-NN)}

Seblum dilakukan proses prediksi dilakukan perhitungan jarak pada variabel prediktor dengan data ordinal menggunakan persamaan (18) dan pada variabel prediktor 
dengan data nominal menggunakan persamaan (17) dengan menggunakan Ms. Excel. Selanjutnya proses prediksi dilakukan dengan function 'fknn' pada matlab yang menghasilkan nilai keanggotaan, matrik konfunsi dan ketepatan klasifikasi. K yang digunakan pada penelitian ini yaitu $\mathrm{K}=1,2, \ldots, 15$. Sebagai contoh, nilai keanggotaan yang diperoleh dengan $\mathrm{K}=1$ yaitu sebagai berikut :

Tabel 10. Nilai Keanggotaan Untuk $K=1$

\begin{tabular}{ccccccccc}
\hline Data & Y1 & Y2 & Y3 & Y4 & Y5 & Y6 & Y7 & Y8 \\
\hline 1 & 0 & 0 & 1 & 0 & 0 & 0 & 0 & 0 \\
2 & 0 & 0 & 1 & 0 & 0 & 0 & 0 & 0 \\
$\cdot$ & $\cdot$ & $\cdot$ & $\cdot$ & $\cdot$ & $\cdot$ &. &. &. \\
1830 & 0 & 0 & - & $\cdot$ &. &. &. &. \\
\hline
\end{tabular}

Berdasarkan Tabel 10, nilai keanggotaan data uji ke-1 untuk $\mathrm{K}=1$ pada kelas 1, kelas 2, kelas 4 , kelas 5, kelas 6 , kelas 7, dan kelas 8 adalaah 0 , sedangkan nilai keanggotaan pada kelas 3 yaitu 1. Sehingga hasil prediksi untuk data uji ke-1 yaitu termasuk pada kelas 3 (suntik), begitu seterusnya hingga data uji ke -1830 . Hasil prediksi dengan $K=1$ secara komulatif diperoleh sebagai berikut :

Tabel 11. Hasil Prediksi Kumulatif dengan $\mathrm{K}=1$

\begin{tabular}{ccccccccc}
\hline & \multicolumn{7}{c}{ Jenis Metode Kontrasepsi (Kategori) } \\
\cline { 2 - 9 } & IUD & MOP & Suntik & Kondom & MOW & Implant & Pil & Tradisional \\
Aktual & 26 & 5 & 1593 & 3 & 35 & 57 & 108 & 3 \\
Prediksi & 23 & 4 & 1617 & 1 & 36 & 47 & 101 & 1 \\
\hline
\end{tabular}

Nilai ketepatan klasifikasi APER dan Press's Q dari $\mathrm{K}=1,2, \ldots, 15$ beberapa memiliki nilai yang hampir sama atau berdekatan. Nilai ketepatan klasifikasi APER dan Press's Q yang memiliki rentang cukup jauh yaitu ditampilkan sebagai berikut :

Tabel 12. Nilai APER dan Ketepatan Klasifikasi FKNN

\begin{tabular}{cccc}
\hline K & APER & Ketepatan Klasifikasi & Press's $Q$ \\
\hline 1 & 0,1885 & 0,8115 & 7884,660 \\
4 & 0,1322 & 0,8678 & 9230,591 \\
$\mathbf{1 1}$ & $\mathbf{0 , 1 2 0 8}$ & $\mathbf{0 , 8 7 9 2}$ & $\mathbf{9 5 1 8 , 0 1 4}$ \\
\hline
\end{tabular}

Berdasarkan Tabel 12 diatas dapat diketahui bahwa ketepatan klasifikasi terbaik pada klasifikasi Fuzzy K-Nearest Neighbor (FK-NN) yaitu dengan K=11. Selain itu nilai Press's $Q$ dari semua K menunjukan bahwa nilai Press's $Q>\chi_{\alpha, 1}^{2}$ yaitu 3,841, sehingga dapat disimpulkan bahwa dengan tingkat keyakinan 95\% metode klasifikasi Fuzzy K-Nearest Neighbor (FK-NN) akurat secara statistik.

\subsection{Perbandingan Ketepatan Klasifikasi}

Hasil ketepatan klasifikasi yang diperoleh dengan Regresi Logistik Multinomial dan Fuzzy K-Nearest Neighbor (FK-NN) yaitu sebagai berikut :

Tabel 13. Perbandingan Ketepatan Klasifikasi

\begin{tabular}{|c|c|c|c|}
\hline Metode Klasifikasi & APER & ketepatan Klasifikasi & PressQ \\
\hline $\begin{array}{c}\text { Regresi Logistik } \\
\text { Multinomial }\end{array}$ & $11,75 \%$ & $88,25 \%$ & 9600,945 \\
\hline $\begin{array}{c}\text { Fuzzy K-Nearest } \\
\text { Neighbor (K=11) }\end{array}$ & $12,08 \%$ & $87,92 \%$ & 9518,014 \\
\hline
\end{tabular}


Berdasarkan hasil pada Tabel 13 menunjukan bahwa ketepatan klasifikasi dari metode Regresi Logistik Multinomial lebih baik dari Fuzzy K-Nearest Neighbor (FK-NN) pada pengelompokan kriteria pemilihan metode kontrasepsi di Kecamatan Bulakamba, Kabupaten Brebes, Jawa Tengah.

\section{KESIMPULAN}

Berdasarkan analisis dan pembahasan yang telah dilakukan diperoleh beberapa kesimpulan sebagai berikut :

1) Klasifikasi Regresi Logistik Multinomial menghasilkan ketepatan klasifikasi sebesar 88,25\% dan nilai Press's Q sebesar 9600,945 pada pengelompokan kriteria pemilihan metode kontrasepsi di Kecamatan Bulakamba, Kabupaten Brebes, Jawa Tengah.

2) Klasifikasi Fuzzy K-Nearest Neighbor (FK-NN) menghasilkan ketepatan klasifikasi sebesar 87,92\% dan nilai Press's Q sebesar 9518,014 pada pengelompokan kriteria pemilihan metode kontrasepsi di Kecamatan Bulakamba, Kabupaten Brebes, Jawa Tengah.

3) Klasifikasi menggunakan Regresi Logistik Multinomial memiliki ketepatan klasfikasi yang lebih baik dari Fuzzy K-Nearest Neighbor (FK-NN) pada pengelompokan kriteria pemilihan metode kontrasepsi di Kecamatan Bulakamba, Kabupaten Brebes, Jawa Tengah.

\section{DAFTAR PUSTAKA}

Bewick, V., Cheek, L., dan Ball, J. 2005. Statistics Review 14: Logistic Regression. Critical Care Vol. 9, No. 1 : Hal. 112-118.

Hosmer, D.W., dan Lemeshow, S . 2000. Applied Logistic Regression. New York : John Wiley and Sons Inc.

Johnson, R., dan Wichern, D. 2007. Applied Multivariate Statistical Analysis. New Jersey : Pearson Education, Inc.

Kristiani, Y.P., Safitri, D., dan Ispiyanti, D. 2015. Klasifikasi Kelompok Rumah Tangga di Kabupaten Blora Menggunakan Multivariate Adaptive Regression Spline (Mars) Dan Fuzzy K-Nearest Neighbor (FK-NN). Gaussian Vol. 4, No. 4 : Hal. 1077-1085.

Li, D., Deogun, J.S., dan Wang, K. 2007. Gene Function Classification Using Fuzzy KNearest Neighbor Approach. Proceedings - 2007 IEEE International Conference on Granular Computing, GrC 2007 : Hal. 644-647.

Prasetyo, E. 2012. Data Mining Konsep dan Aplikasi Menggunakan Matlab. Yogyakarta : Penerbit Andi.

Puspita, D., Suparti., dan Wilandari, Y. 2014. Klasifikasi Tingkat Keluarga Sejahtera Dengan Menggunakan Metode Regresi Logistik Ordinal dan Fuzzy K-Nearest Neighbor. Gaussian Vol. 3, No. 4 : Hal. 645-653.

World Health Organization (WHO). 2016. Selected Practice Recommendations for Contraceptive Use. Switzerland: WHO Press. 